\title{
Bioecology of desert truffles in the province of Figuig in Eastern Morocco
}

\section{Bioecología de las trufas del desierto en la provincia de Figuig en Marruecos Oriental}

\author{
Fatima Zohra Bermaki, Lahsen Khabar, Amal Ezzanega \\ Mycologie Forestière et Trufficulture, MycoTruf, Department of Biology, Faculty of Sciences, Mohammed V University, Rabat, Morocco \\ Lahsen Khabar, e-mail: f.zahra.bermaki@gmail.com
}

\section{SUMMARY}

Background: The phytosociology, host plant and diversity of dessert truffles in northeastern Morocco are very little known worldwide. Objective: To evaluate some general and specific parameters of phytosociology, host plant and diversity of desert truffles in eastern Morocco.

Methods: Ten pilot productive sites located in the province of Figuig, Morocco were evaluated. Soil characteristics were evaluated and host plants and species of truffles were identified under field conditions.

Results and conclusion: Phytosociological results revealed the abundance of the herbaceous Helianthemum ledifolium as dominant host plant in eight sites in Abbou Lakhal and Bni Guil. Meanwhile, the perennial Helianthemum lippii dominated two sites in the Northwestern part of the study area. The truffles Tirmania nivea, Tirmania pinoyi, Terfezia claveryi, Terfezia boudieri and Picoa juniperi were identified in the studied areas. Species of the genus Tirmania were abundant in Bni Guil and those belonging to the genus Terfezia dominated in Abou Lakhal. The genus Picoa was identified only in one site. This works shows that the host plants and the climatic conditions influence the distribution of desert truffles in eastern Morocco.

Keywords: Desert climate, Desert truffles, Helianthemum ledifolium, Helianthemum lippii, Terfezia, Tirmania, Picoa.

\section{RESUMEN}

Antecedentes: La fitosociología, y diversidad de plantas hospederas y de trufas del desierto en el noreste de Marruecos ha sido escasamente estudiada a nivel mundial.

Objetivo: Evaluar algunos parámetros generales y específicos de la fitosociología, y la diversidad de las plantas hospederas y la diversidad de trufas del desierto en el noreste de Marruecos.

Métodos: Se evaluaron diez sitios productivos piloto ubicados en la provincia de Figuig, en Marruecos. Se evaluaron las características del suelo y se identificaron las plantas hospederas y la diversidad de trufas en condiciones de campo.

Resultados y conclusión: Los resultados fitosociológicos revelaron la a bundancia de la planta herbácea Helianthemum ledifolium como planta huésped dominante en ocho sitios en Abbou Lakhal y Bni Guil. Mientras tanto, la planta perenne Helianthemum lippii dominó dos sitios en la parte noroeste del área de estudio. Las trufas del desierto Tirmania nivea, Tirmania pinoyi, Terfezia claveryi, Terfezia boudieri y Picoa juniperi fueron identificadas en las áreas estudiadas. Las especies del género Tirmania fueron abundantes en Bni Guil y las pertenecientes al género Terfezia dominaron en Abou Lakhal. El género Picoa fue identificado solo en un sitio. Este trabajo muestra que las plantas hospederas y las condiciones climáticas influyen en la distribución de las trufas del desierto en el este de Marruecos.

Palabras clave: Clima desértico, trufas del desierto, Helianthemum ledifolium, Helianthemum lippii, Terfezia, Tirmania, Picoa. 


\section{INTRODUCTION}

Desert truffles "Terfass" are mycorrhizal fungi that grow almost exclusively in semi-arid and arid zones. Mycorrhizas are worldwide symbiotic associations established between certain soil fungi and most vascular plants and are fundamental in optimizing plant fitness and soil quality. Mycorrhizal symbioses improve the resilience of plant communities against environment stresses, including nutrient deficiency drought and soil disturbance (Barea et al., 2011).

The desert truffles "Terfass" grow in the sand, under herbaceous angiosperms, under Cistus and Helianthemum (Alsheikh, 1984), the most common host plants of "Terfess" being generally herbaceous or perennial Helianthemum species (Awameh and Alsheikh, 1980; Khabar et al., 1994; 1999; 2001; 2014; Fortas and Chevalier, 1990, Roth-Bejerano et al., 1990; Morte and Honrubia, 1997).

Generally, "Terfass" occur in semiarid and arid areas with hot climates in almost all the Mediterranean basin especially in North Africa and Middle East countries. Diez et al. (2002) grouped them based on climatic and soil characteristics of the area of origin and they found that Helianthemum hosts have a wide edaphic tolerance which explains the occurrence of several truffle species hosted by Helianthemum in both acid and basic soil. The formation of truffles depends on several factors such as the rainy season (including length and amount of precipitation), the soil types and some abiotic characteristics as water availability and climatic conditions.

Desert truffles grow in arid desert climate characterized by very hot summers with high humidity and relatively cooler winters (Mandeel and Al-Laith, 2007). In Algeria the productive area of desert truffles are characterized by its aridity and high average temperatures (Bradai et al., 2013). A factor of paramount importance in the formation of dessert truffles are the autumnal rains (Bradai et al., 2013). Khabar et al. (2001; 2016) and Zambonelli et al. (2014) described the area localized in the East and South eastern Morocco in arid and subdesert climate and calcareous soil and they identified five species of desert truffles belonging to three genera: Tirmania pinoyi, Tirmania nivea, Terfezia boudieri, Terfezia claveryi and Picoa juniperi associated to Helianthemum lipii as perennial host plant and other species of herbaceous Helianthemum. H. lippii hosted all the desert truffles species in arid climate including T. boudieri and T. claveryi in the Arab Peninsula (Alsheikh, 1994); T. boudieri, T. claveryi, Tirmania pinoyi, T. nivea and Picoa juniperi in the Moroccan High plateaus (Khabar et al., 2005) and Médenine in Tunisia (Slama et al., 2010); and Terfezia boudieri in Negev desert (Sitrit et al., 2014).

This work aims to study some biological (phytosociology, host plants and presence of shrubs) and abiotic ecological parameters (climate and soil) which influence the distribution of the desert truffles in pilot productive Moroccan areas in order to identify its general characteristics and particularities.

\section{MATERIAL AND METHODS}

\section{Study areas}

The study area is administratively located in the province of Figuig, in the eastern part of the rural commune of Bni Guil, which is a rural commune placed in the southeastern part of Morocco. The study area (Figure 1) is naturally limited by a range of mountains (mountain in Arabic $=J e b e l$ ) into the chain of the high Atlas of the southern side by the most important summit, the biological and ecological interest site of Jebel Grouz (1920 m a.s.l.) representing a natural territorial limit between Morocco and Algeria.

The choice of the studied sites was based on the investigation of the nomad population, seasonal collectors, and truffle production data of 2013 by $\mathrm{kg}$ per a three-month season in various production sites. These data were obtained from the Provincial Department of Agriculture of Figuig. No data were recorded recently due to the great production fluctuation and low harvests.

\section{Ecology}

Desert truffles "Terfass" soil of 13 productive site, six in east and seven in the western part of the study area were analyzed (Table 1) (PDPEO, 2005). Rainfall and temperature data were obtained from climate-data.org. For Bni Guil we used Bouarfa city climate data station, the urban center of Bni Guil (Table 2). 


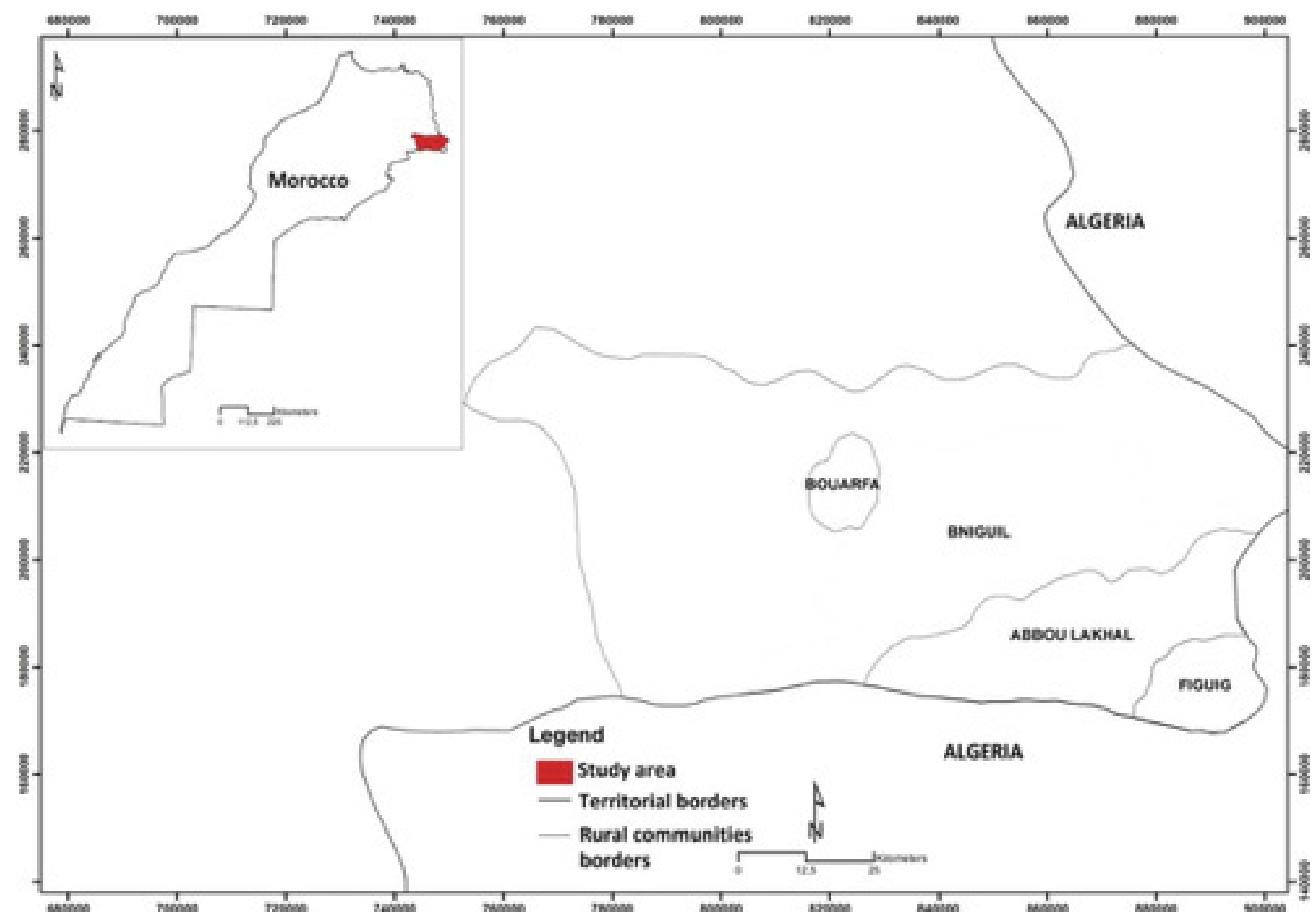

Figure 1. Study area located in the borders of Morocco and Algeria.

Table 1. Average soil parameters of the study area

\begin{tabular}{|c|c|}
\hline \multicolumn{2}{|l|}{ Texture (\%) } \\
\hline Clay & 17.5 \\
\hline Silt & 7.5 \\
\hline Sand & 44.5 \\
\hline $\mathrm{pH}$ & 8.25 \\
\hline \multicolumn{2}{|c|}{ Chemical composition } \\
\hline Organic matter \% & 0.9 \\
\hline $\mathrm{K}_{2} \mathrm{O}\left(\mathrm{mg} \cdot \mathrm{kg}^{-1}\right)$ & 389.86 \\
\hline $\mathrm{P}_{2} \mathrm{O}_{5}\left(\mathrm{mg} \cdot \mathrm{kg}^{-1}\right)$ & 12.825 \\
\hline $\mathrm{N}-\mathrm{NH}_{4}\left(\mathrm{mg} \cdot \mathrm{kg}^{-1}\right)$ & 0.35 \\
\hline $\mathrm{N}-\mathrm{NO}_{3}\left(\mathrm{mg} \cdot \mathrm{kg}^{-1}\right)$ & 15.65 \\
\hline $\mathrm{MgO}\left(\mathrm{mg} \mathrm{kg}^{-1}\right)$ & 272.585 \\
\hline $\mathrm{CaO}\left(\mathrm{mg} \cdot \mathrm{kg}^{-1}\right)$ & 2913.815 \\
\hline
\end{tabular}

\section{Mycological and phytosociological study}

Mycological and phytosociological surveys were conducted according to the method defined by Braun-Blanquet (1952), in an area of $100 \mathrm{~m}^{2}$ of a representative and homogeneous harvest point. Knowing that every productive site can contain several harvest points. These areas included the dominant perennials and herbaceous strata identified directly on the field. The distinction among truffle species is typically based on both macromorphology and micromorphological characters (Malençon, 1973). In the laboratory, small fragments were taken from the gleba, crushed and mounted in $\mathrm{KOH} \mathrm{5 \% .} \mathrm{The} \mathrm{observation} \mathrm{by} \mathrm{light} \mathrm{micros-}$ copy allowed the observation of ascospores and to specify their sizes, shapes, color, and the degree of maturity of the truffles by using the Key of Tuberals of Morocco (Khabar, 2002). 


\section{RESULTS AND DISCUSSION}

\section{Abiotic conditions}

The study area is relatively mountainous. Every site nomenclature refers to a relief; there is the lowland, the Jebel foothills (Jebel=Mountain), (Dayet $=$ Lake), $($ Maader $=$ Lowland where there is an intersection). It is therefore a very clear contrast. Nine productive sites were selected for this study, knowing that, each site could contain from one to several harvest points, the surface of a homogenous site varied, and therefore was linked to another close site if there was no orographic barrier between them.

(i) Climate and soil: Climatic parameters are among the most important abiotic factors that effectively control the occurrence of desert truffles (Trappe et al., 2008 a, b). In eastern Moroccan steppes, vegetation is affected by climate; its intensity seems more amplified in the presence of the most pressing anthropic factors on pastoral resources (Bechchari et al., 2014). The climate in our study area was desert with moderate rainfall in both winter and summer, with average temperatures of $17.9^{\circ}$ $\mathrm{C}$ in Bni Guil (k: dry and cold) and $18.6^{\circ} \mathrm{C}$ in Abbou Lakhal (h: dry and hot). The average annual rainfall was $170 \mathrm{~mm}$, with June and July as the driest months with $1.5 \mathrm{~mm}$ of average rainfall. On average, $57 \%$ of the rain fell before the end of March and nearly $92 \%$ by the end of April (PDPEO, 2005). Usually good annual rainfall from October to March makes a good harvesting season desert truffles in Algeria (Bradai et al., 2014). Autumnal precipitation was higher, $21 \mathrm{~mm}$ in October for Abou lakhal and $25 \mathrm{~mm}$ in November for Bni Guil, which is called Choula by local and nomad population. Meteorologically, heavy rain showers during mild to warm weather $\left(25-30{ }^{\circ} \mathrm{C}\right)$ coupled with heavy evening or early morning dewfalls and thunder and lightning has been considered an essential requirement for truffle formation (Al-Rahmah, 2001).

(ii) Soils analysis. This showed a sandy structure, very low contents of organic matter, alkaline $\mathrm{pH}$ and very low levels of nitrogen and phosphorus. Corresponding to the fact that soils with the low $\mathrm{P}$ availability is highly correlated to a low organic matter, from 10 to $20 \mathrm{mg} / \mathrm{kg}$ (Bonifacio and Morte, 2014). On the other hand, the potassium and calcium contents were high. According to Morte et al. (2009) variations in the content of carbonate and $\mathrm{pH}$ affect the presence of truffle species.

\section{Phytosociology and mycological diversity}

Phytosociology: The dominant species were Anabasis aretioides, Hammada scoparium, and Helianthemum appeninum. The host plants Helianthemum lippii (Figure 2) called locally "Gurish" and Helianthemum ledifolium called locally "Tegsis" were included into an Anabasis aretioides Bugen steppe studied in Oriental Morocco (Guinet, 1954). Dominance of $A$. aretioides is used by harvesters as an important parameter to identify a desert truffle area. The formation characterized the rocky soils vegetation and covers quite large areas between Bouarfa and Figuig under a Desert bioclimate (Ben El Mostapha et al., 2001).

No desert truffles were collected under the perennial Helianthemum apenninum and no other host plant was signaled by nomads and seasonal harvesters. Ninety percent of native people in Algeria do their truffle searching where host plants Helianthemum spp. are abundant (Bradai et al., 2014). Plants from the genus Helianthemum were the only host plants and sometimes desert truffles were linked to their roots. In Mader Msarin and Hammourzag, Tirmania and Terfezia species were identified under Helianthemum lippii when Helianthemum ledifolium was totally absent. On the other hand, and despite the presence of the perennial Helianthemum lippii in Mdaouer site no desert truffles were recorded, whereas Helianthemum ledifolium was dominant (Table 3).

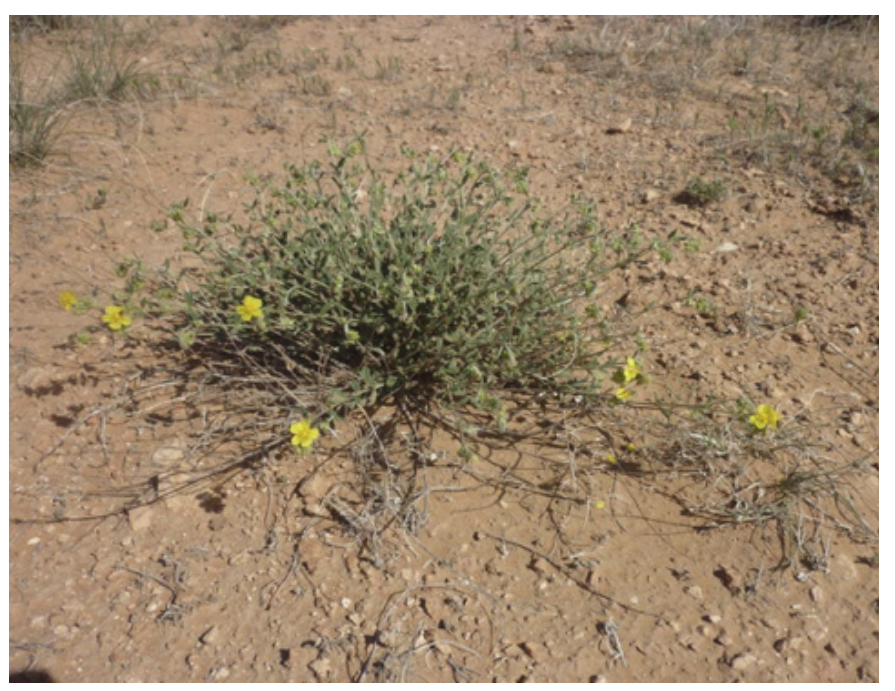

Figure 2. Helianthemum lippii host plant of desert truffles growing under field conditions. 


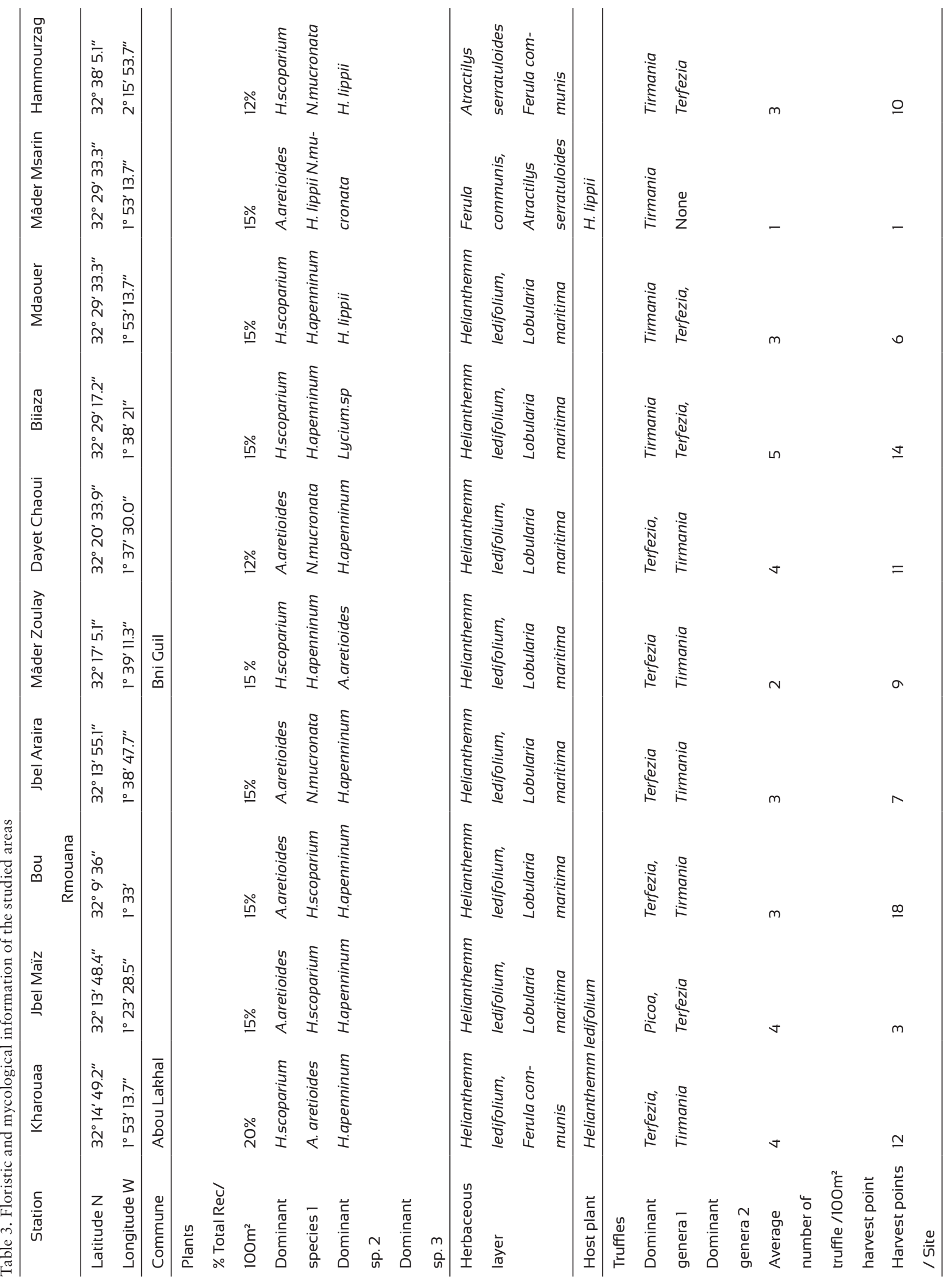


Mycological diversity: There was a big variation in the number of desert truffles collected and the dominant species collected. We had some particularities in the site of Jbel Maiz characterized by the presence of Picoa juniper (Figure 3). The mycological study showed variability in the number of harvest point's number per site and the number of desert truffles collected per harvest point. A dominance of ascomata belonging to the genus Terfezia (Figure 4) in Abbou Lakhal and dominance of the genus Tirmania (Figures 5 and 6) were recorded in Bni Guil.

A particular presence of Picoa genus represented in Morocco by one species Picoa juniperi by (Khabar et al., 2001) was identified in Jbel Maiz site. This has been considered as an infrequent species by Calogne (1982).

The average number of desert truffles collected in harvesting points of $10 \mathrm{~m}^{2} \mathrm{x} 10 \mathrm{~m}^{2}$ ranged from 1 to 4 . In the same site it was possible to find a variation of ascomata from a harvest point to another (Table 3).

In addition to that, soil and climate factors were favorable for the development of other non-mycorrhizal fungi as Pleurotus eryngii an edible mushroom hosted by Ferula communis consumed locally but having a moderate economic interest compared to "Terfass".

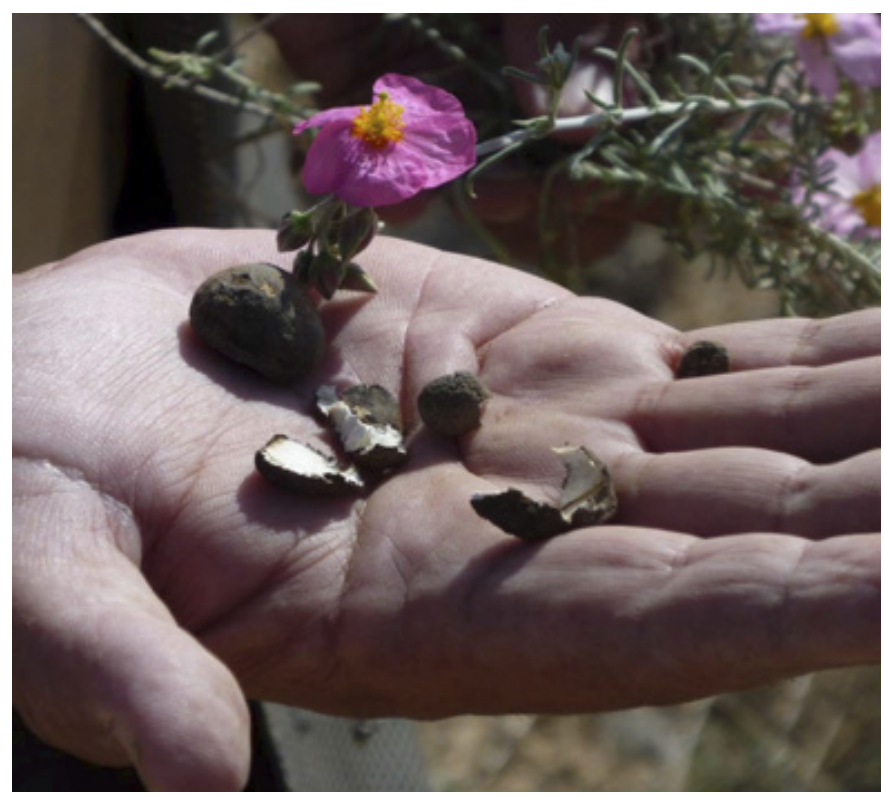

Figure 3. Picoa juniper showing its small size.

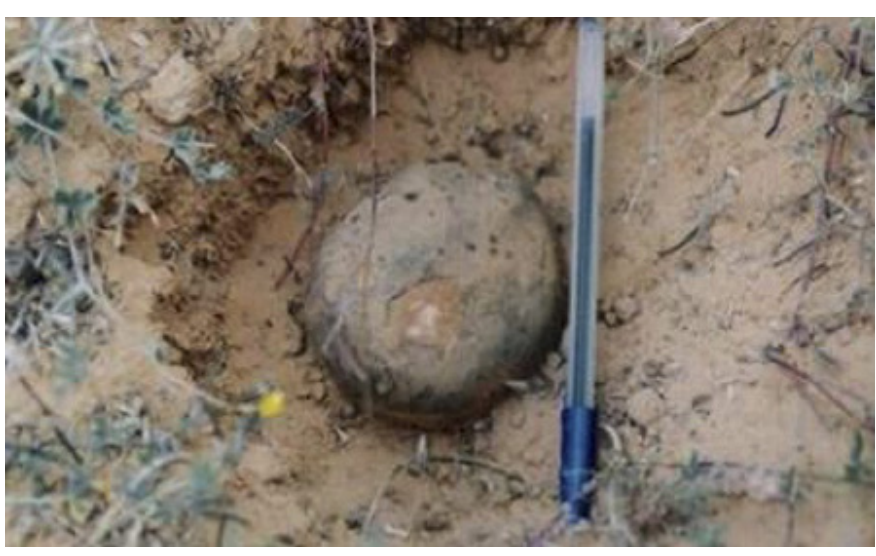

Figure 4. Terfezia boudieri growing under natural conditions.

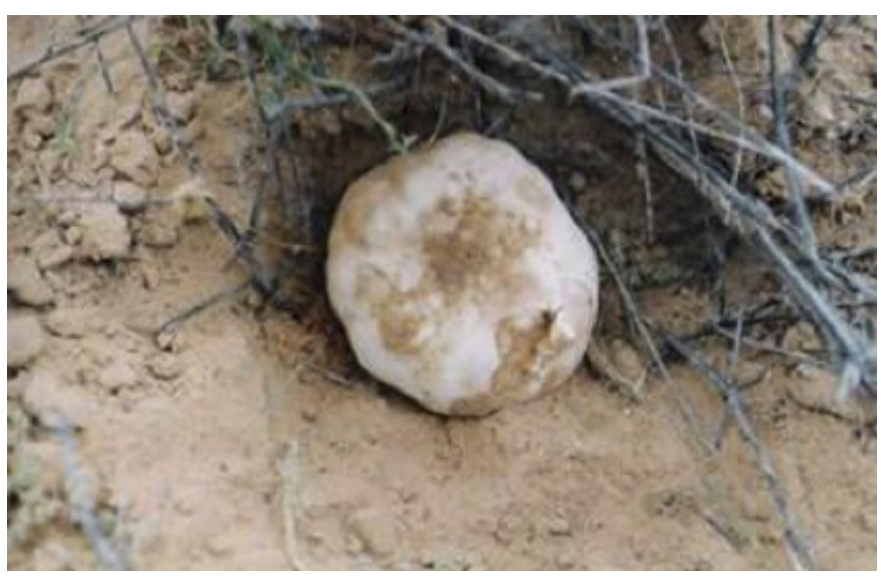

Figure 5. Tirmania nivea growing under natural conditions.

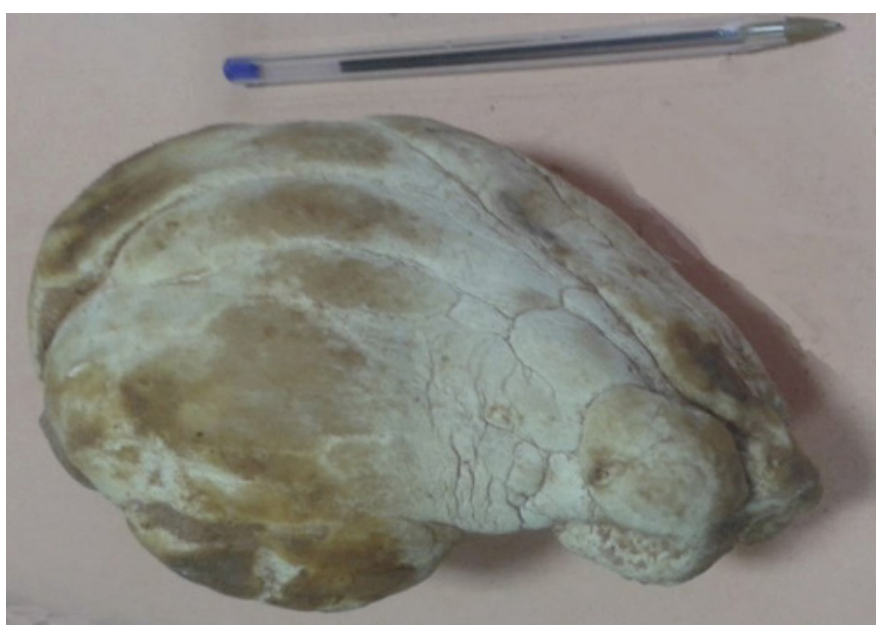

Figure 6. Tirmania nivea showing the big size that can reach. 


\section{CONCLUSION}

Climatic and edaphic conditions favor the mycorhization and development of the following desert truffles: Tirmania nivea, $T$. pinoyi, Terfezia claveryi, T. boudieri and Picoa juniperi in the study area. In our study area we have a Desert climate with an average annual rainfall of $170 \mathrm{~mm}$ and some rainfall in October and November. Phytosociological and mycological surveys showed a dominance and presence of only one host plant Helianthemum ledifolium in Abbou Lakhal conditioned by microclimate created by orographic reliefs. Meanwhile, mycological surveys showed a dominance of Terfezia then Tirmania species and the presence of a rare species of Picoa in one site. We can conclude that our study highlight the importance of biotic and abiotic factors in the distribution of desert truffles in eastern Morocco.

\section{ACKNOWLEDGMENTS}

The authors wish to express their gratitude to the Provincial Department of Agriculture DPA of Figuig. We appreciate the precious help of: Mr. Chlih, Mr. Chambouleyron, Mr. Boullenger (ECWP of Missour), Mr. Touil (ECWP of Bouarfa) and Mrs. Jebari Aziza engineer in the HCEFLD. Also the valuable help of the citizens and nomads of Bouarfa, Bni Guil, Abou Lakhal and Figuig is acknowledged.

\section{REFERENCES}

Al-Rahmah, A.N., 2001. Truffle of deserts and dungles (In Arabic). King Saud University Publications, Riyadh, Saudi Arabia.

Alsheikh, A.M., 1994. Taxonomy and mycorrhizal ecology of the desert truffles in the genus Terfezia. PhD. Thesis, Oregon State University, Corvallis.

Alsheikh, A.M., 1984. Mycorrhizae of annual Helianthemum species formed with desert truffles. In: Molina, R., (ed). Mycorrhizae. Bend, OR, Proceedings of the Sixth North American Conference. Pp. 25-29.

Awameh, M.S., A.M. Alsheikh, 1980. Ascospore germination of black kame (Terfezia boudieri). Mycologia 72: 50-54.

Barea, J.M., J. Palenzuela, P. Cornejo, I. Sánchez-Castro, C. NavarroFernández, A. López-García, B. Estrada, R. Azcón, N. Ferrol, C. Azcón-Aguilar, 2011. Ecological and functional roles of mycorrhizae in semi-arid ecosystems of Southeast Spain. Journal of Arid Environments 75: 1292-1301.

Bechchari, A., A. El Aich, H. Mahyou, B. Baghdad, M. Bendaou, 2014. Study of the degradation of steppic rangelands in Béni Mathar and Maâtarka communes (Northeastern of Morocco). Journal of Materials and Environmental Science 5: 2572-2583.

Ben, El Mostafa S., B. Haloui, A. Berrichi, 2001. Contribution a l'étude de la végétation steppique du Maroc oriental : Transect Jerrada, Figuig. Acta Botánica Malacitana 26: 295-301.
Bonifacio, E., A. Morte, 2014. Soil properties. Africa In: Kagan, Z.V. (ed.), Desert truffles, soil biology. Spring- Verlag Berlin Heidelberg. Pp. 57-67.

Bradai, L., S. Bissati, H. Chenchouni, 2014. Desert truffles of the North Algerian Sahara: diversity and bioecology. Emirates Journal of Food and Agriculture 26: 425-435.

Bradai, L., S. Bissati, H. Chenchouni, K. Amrani, 2015. Effects of climate on productivity of some species of desert truffles beneath hyper-arid conditions. International Journal of Biometeorology 117: 213-229.

Bradai, L, S. Bissati, H. Chenchouni, 2013. Etude mycologique et bioécologique de la truffe blanche du désert (Tirmania nivea Desf. Trappe.1971) dans la région de Oued M’ya (Ouargla, Sahara algérien). Revue des Bioressources 3: 6-14.

Braun-Blanquet, J., 1952. Prodrome des groupements végétaux de la France Mediterranee C.N.R.S. Ser. Carte group. veg. et dir. Carte group. veg. d' Afrique du Nord, Paris.

Calonge, F.D., 1982. Adiciones al catalogo de hongos hipogeos de España. Garcia de Orta, Sér. Est. Agron., Lisboa 9: 143-146.

Diez, J., J.L. Manjon, F. Martin, 2002. Molecular phylogeny of the mycorrhizal desert truffle (Terfezia and Tirmania). Host specificity end edaphic tolerance. Mycologia 94: 247-259.

Fortas, Z., G. Chevalier, 1992. Effet des conditions de culture sur la mycorhization de l'Helianthemum guttatum par trois espèces de terfez des genres Terfezia et Tirmania d'Algérie. Canadian Journal of Botany 70: 2453-2460.

Guinet, Ph., 1954. Carte de la Végétation de l'algérie. Feuille de Beni Abbes au 1/200000. Argel. http://dx.doi.org/10.1007/s00484014-0891-8.

Khabar, L., L. Najim, M.C. Janex-Favre, A. Parguey-Leduc, 1994. L'ascocarpe de Terfezia leonis Tul. (Discomycetes,Tuberales). Cryptogamie Mycologie 15:187-206.

Khabar, L., L. Najim, G. Moreno, J. Diez, J.L. Manjon, A. Morte, A. Gutierrez, M. Honrubia, M. Abourouh, 1999. Truffles in Morocco. XIII Congress of European Mycologists, Alcalá de Henares, Madrid, Spain.

Khabar, L., L. Najim, M.C. Janexe-Favre, A. Parguey-Leduc, 2001. Contribution à l'étude de la flore marocaine mycologique du Maroc: les truffes marocaines, Discomycètes. Bulletin Société Mycologique de France 117: 213-229.

Khabar, L., 2002. Etudes pluridisciplinaires des truffes du Maroc et perspectives pour l'amélioration de production des «Terfess » de la foret de la Mamora. PhD. Thesis, Université Mohammed- V, Rabat.

Kahbar, L., A. Slama, M. Neffati, 2005. Terfess common to Morocco and Tunisia. Actes of IWEMM 4, Murcia, Spain.

Khabar, L., 2014. Mediterranean Basin: North Africa. In: Kagan V. Z., (ed.), Desert truffles, soil biology. Spring-Verlag, Berlin. Pp. 143158.

Khabar, L., 2016. Les Terfess et les Truffes du Maroc. Editions Universitaires Européenes, Paris.

Malençon, G., 1973. Champignons hypogés du nord de l'Afrique-Iascomycetes. Persoonia 7: 261-288.

Mandeel, Q.A., A.A. Al-Laith, 2007. Ethnomycological, aspects of the desert truffle among native Bahraini and non-Bahraini peoples of the Kingdom of Bahrain. Journal Ethnopharmacology 110: 118-129.

Morte, M.A., M. Honrubia, 1997. Micropropagation of Helianthemum almeriense. In: Bajaj, Y.P.S. (ed.), Biotechnology in agriculture and forestry 40. High-Tech and Micropropagation VI. Springer-Verlag, Berlin. Pp. 163-177.

Morte, A., M. Zamora, A. Gutiérrez, M. Honrubia, 2009. Desert truffle cultivation in semiarid Mediterranean areas. In: AzcónAguilar, C., J.M. Barea, S. Gianinazzi, V. Gianinazzi-Pearson (eds.), Mycorrhizae: functional processes and ecological impact. 
Springer, Berlin. Pp 221-233. doi:10.1007/978-3-540-879787_15.

PDPEO, 2005. Projet de développement de parcours de l'Oriental. Marché $\mathrm{N}^{\circ}$ 2/96-97/DPA/52/DP, Diversification des ressources naturelles: Truffes du désert. Ministère de l'agriculture du développement rural et de la pêche maritime, Rabat.

Roth-Bejerano, N., D. Livne, V. Kagan-Zur, 1990. HelianthemumTerfezia relation in different growth media. New Phytologist 114: 235-238.

Sitrit, Y., N. Roth-Bejerano, V. Kagan-Zur, T. Turgeman, 2014. PreSymbiotic interaction between the desert truffle Terfezia boudieri and its host plant Helianthemum sessiliflorum Africa. In: Kagan, V.Z. (ed.), Desert truffles, soil biology, Spring- Verlag, Berlin Heidelberg.

Slama, A., Z. Fortas, A. Boudabous, M. Neffati, 2010. Cultivation of an edible desert truffle (Terfezia boudieri Chatin). African Journal of Microbiology Research 4: 2350-2356.
Trappe, J.M., A.W. Claridge, D. Arora, W.A. Smit, 2008a. Desert truffles of the African Kalahari: ecology, ethnomycology, and taxonomy. Economic Botany 62: 521-529. doi:10.1007/s12231008-9027-6.

Trappe, J.M., A.W. Claridge, D.L. Claridge, L. Liddle, 2008b. Desert truffles of the Australian outback: ecology, ethnomycology, and taxonomy. Economic Botany 62: 497-506. doi:10.1007/s12231008-9041-8.

Zambonelli, A., D. Donnini, G.L. Rana, S. Fascetti, G.M.N. Benucci, M. Iotti, A. Morte, L. Khabar, A. Bawadekji, F. Piattoni, R. Compagno, G. Venturella, 2014. Hypogeous fungi in Mediterranean maquis, arid and semi-arid forests. Plant Biosystems: Official Journal of the Societa Botanica Italiana 148: 392-401. doi: 10.1080/11263504.2013.877537. 